\title{
Epidermal Growth Factor Acts as a Corticotropin-releasing Factor in Chronically Catheterized Fetal Lambs
}

\author{
Daniel H. Polk,* M. Gore Ervin, James F. Padbury, Robert W. Lam, Anita L. Reviczky, and Delbert A. Fisher \\ Perinatal Research Laboratory, Departments of Pediatrics and Obstetrics, Harbor-University of California \\ at Los Angeles (UCLA) Medical Center, UCLA School of Medicine, Torrance, California 90509
}

\begin{abstract}
Epidermal growth factor (EGF) has been reported to stimulate adrenocorticotropin hormone (ACTH), growth hormone and prolactin secretion from pituitary tissue in vitro, and in large doses evokes ACTH secretion in adult sheep in vivo. In order to assess a possible role for EGF in the pituitary hyperfunction characteristic of the in utero fetus, we measured changes in plasma immunoreactive ACTH concentrations after acute administration of saline, purified mouse EGF or synthetic ovine corticotropin releasing factor (CRF) to chronically catheterized fetal sheep. Both CRF and EGF were associated with increases in plasma immunoreactive ACTH concentrations. Peak values $60 \mathrm{~min}$ after 10- $\mu \mathrm{g}$ injections of either EGF or CRF increased from baseline ACTH values of $61 \pm 11 \mathrm{pg} / \mathrm{ml}$ to $191 \pm 37$ and $178 \pm 25 \mathrm{pg} / \mathrm{ml}$, respectively. Dose-response studies indicate that at low doses ( $<20 \mu \mathrm{g}$ ) EGF is as potent a stimulus for ACTH release as CRF. EGF infusion was not associated with detectable changes in circulating $\mathrm{CRF}$, catecholamines, arginine vasopressin levels, or plasma growth hormone concentrations. We speculate that EGF may be important in the regulation of pituitary function in the developing mammalian fetus.
\end{abstract}

\section{Introduction}

Epidermal growth factor (EGF) ${ }^{1}$ is a $6,000-D$ peptide first purified from mouse submandibular glands (SMG) (1). The human counterpart of EGF, urogastrone, was isolated from urine and named for its ability to inhibit gastric acid secretion (2). EGF acts as a mitogen or progression factor for mitosis in a variety of cell lines, and has important developmental effects $(3,4)$. It promotes eyelid opening, palate development, tooth eruption, and gut development in rodents; it is important in the maturation and function of hair follicles in several species; and lung maturation and alveolarization are promoted by EGF in the sheep (3-6). EGF and EGF receptors have been identified in fetal rodent tissues and a role for EGF in fetal development has been

Address reprint requests to Dr. Polk, King-Drew Medical Center, Department of Pediatrics, 12021 Wilmington Avenue, Los Angeles, CA 90059.

Received for publication 14 July 1986.

1. Abbreviations used in this paper: ANOVA, analysis of variance; AVP, arginine vasopressin; $\mathrm{CRF}$, corticotropin-releasing factor, $\mathrm{E}$, epinephrine; EGF, epidermal growth factor; $\mathrm{CH}$, growth hormone; NE, norepinephrine; oCRF, ovine CRF; POMC, proopiomelanocortin; SMG, submandibular glands.

J. Clin. Invest.

(c) The American Society for Clinical Investigation, Inc.

0021-9738/87/03/0984/05 $\$ 1.00$

Volume 79, March 1987, 984-988 proposed $(5,7)$. Significant levels of EGF are found in human amniotic fluid (8).

Hormone-EGF interactions have been reported and it has been proposed that EGF may mediate the developmental effects of selected hormones (9). EGF production in mouse SMG is thyroxine and testosterone responsive and urine EGF production and kidney EGF concentrations are thyroxine responsive in the mouse (10-12). EGF concentrations in several other tissues including liver, skin, and eye also are thyroxine responsive (13, $14)$ as is EGF receptor binding in skin and liver $(15,16)$. Finally, EGF has been shown to evoke hormone secretion from cultured anterior pituitary cells (17-19), and a recent paper reports that EGF augments ACTH release in vivo in adult sheep (20).

The circulating levels of anterior pituitary hormones, particularly ACTH, growth hormone (GH), and gonadotropins are markedly elevated in the mammalian fetus during the latter half of gestation (21). These high levels presumably are due to relatively high rates of secretion, but the mechanism(s) remain obscure (21). A role for EGF and perhaps other growth factors in this pituitary hyperactivity is possible. To explore this hypothesis we assessed the effects of acute EGF administration on plasma ACTH and GH levels in the chronically catheterized sheep fetus. Dose response studies were conducted to compare relative potencies of EGF and CRF as corticotropin releasing factors. In addition we measured the blood levels of CRF, arginine vasopressin (AVP) and catecholamines after EGF injection to better characterize the mechanism of the EGF effect on ACTH release.

\section{Methods}

Time-dated pregnant ewes with single fetuses were obtained from our usual source (Nebeker Ranch, Lancaster, CA) and acclimated to laboratory conditions and feed. Laparotomies were conducted in five ewes with fetuses at 134-136 d gestation using continuous ketamine anesthesia. Under sterile conditions, fetal arterial and venous hindlimb catheters were inserted and exteriorized onto the ewe's flank. Starting at 142-144 d gestation, fetuses were randomly injected intravenously with either 3 $\mathrm{ml}$ of $0.9 \%$ saline, $10 \mu \mathrm{g}(1.6 \mathrm{nmol})$ of mEGF or $10 \mu \mathrm{g}(2 \mathrm{nmol})$ of ovine (o)CRF. The saline injected fetuses served as negative and the oCRF injected fetuses served as positive controls. Injections were conducted on successive mornings of the study period.

Pregnant ewes $(n=5)$ for the dose response studies were catheterized at a gestational age of 118-126 d and studied after $5 \mathrm{~d}$ of postoperative recovery. All ewes were treated for $5 \mathrm{~d}$ after catheterization with daily intravenous chloramphenicol and gentamycin. The dose-response fetuses were randomly injected with $0.5,1,2,5,10$, or $20 \mu \mathrm{g}$ of either mEGF or OCRF in $3 \mathrm{ml}$ of $0.9 \%$ saline on successive mornings. To minimize the effects of gestational age on dose response data, paired doses of EGF and CRF were administered on alternate days; if a fetus received EGF on one day an equivalent dose of CRF was injected the next. Every seventh day, the fetus received $3 \mathrm{ml}$ of $0.9 \%$ saline as a control. Fetal blood samples for both sets of studies were collected before and at 30 and $60 \mathrm{~min}$ after injection. Blood samples were immediately processed into plastic tubes for hormone assays. All samples were processed in 


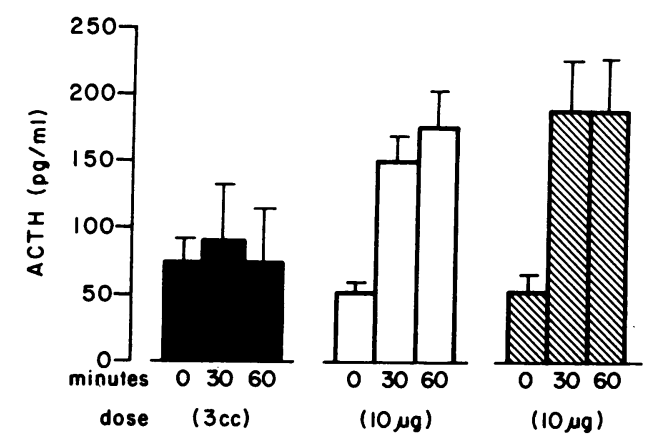

Figure 1. Plasma ACTH activity after saline (solid bars), oCRF (open bars) and mEGF (hatched bars) infusion in fetal sheep. Both oCRF and $\mathrm{mEGF}$ are associated with an increase in ACTH activity $(P$ $<0.001)$.

duplicate. Fetal heart rate, arterial blood pressure, and arterial blood gases were measured at each sampling time.

Materials. EGF was purified to homogeneity from adult Swiss Webster mice as reported previously $(14,22)$. The final product migrated as a single band by polyacrylamide gel electrophoresis and had an apparent molecular mass approximating 6,000 D. oCRF, synthesized using solid phase techniques, was purchased commercially (Bachem Co., Torrance, CA) and used for injection and for development of the radioimmunoassay.

Hormone assays. ACTH was determined by radioimmunoassay (RIA) in EDTA plasma using a second antibody-polyethylene glycol procedure after QUSO extraction (North America Silica Co., Teterboro, NJ) at the Nichols Institute, San Juan Capistrano, CA (23). The antiserum (from Dr. Donald West, University of Utah School of Medicine) was used in a final dilution of 1:75,000 (23); ACTH from Bachem Co. was labeled with ${ }^{125}$ I using the chloramine T method (24), and the labeled hormone was purified by HPLC. The same Bachem material was used as standard in the RIA. Intraassay and interassay coefficients of variation were 9 and $13.2 \%$, respectively. Sensitivity of the assay was $8 \mathrm{pg} / \mathrm{ml}$ (at $90 \% \mathrm{~B} / \mathrm{B}_{0}$ ).

Arginine vasopressin was determined in plasma after Sep-Pac C18 cartridge (Waters Associates, Milford, MA) elution using our previously described RIA (25). The sensitivity of this assay was $1 \mathrm{pg} / \mathrm{ml}$. Epinephrine (E) and norepinephrine (NE) were determined in EGTA/GSH plasma by radioenzymatic assay with a sensitivity approximating $2 \mathrm{pg} / \mathrm{ml}$ (26). Growth hormone was measured by RIA using material generously provided by the National Institute of Arthritis, Diabetes, Digestive and Kidney diseases. Sensitivity of this assay was $100 \mathrm{pg} / \mathrm{ml}$.

CRF was measured by a homologous RIA developed in our laboratory. Synthetic $O C R F$, conjugated to thyroglobulin using carbodiimide, was dialyzed, suspended in complete Freund's adjuvant (Miles Laboratory Inc., Naperville, IL) and used to develop antisera in virgin female New Zealand white rabbits. The antiserum utilized for the RIA bound $40 \%$ of ${ }^{125}$ I-labeled $O C R F$ at a final dilution of 1:320,000. Synthetic oCRF was iodinated using the chloramine $T$ method (24) and the label purified using an $80-\mathrm{cm}$ Sephadex G-50 column equilibrated with $0.01 \mathrm{M}$ phosphate-buffered saline (PBS) with $0.01 \mathrm{M}$ EDTA, $0.01 \%$ bovine serum albumin (BSA), $\mathrm{pH} 7.4$ at $4^{\circ} \mathrm{C}$.

The RIA was conducted in $10 \times 75$-mm glass tubes; $200 \mu \mathrm{l}$ assay buffer (0.01 M PBS, 0.01 M EDTA, 0.1\% BSA, pH 7.4) $50 \mu$ l antiserum $1: 40,000$ in assay buffer, and $100 \mu l$ of serum or OCRF standard in assay buffer were added to each tube and incubated for $24 \mathrm{~h}$ at $4^{\circ} \mathrm{C}$. At $24 \mathrm{~h}$, $50 \mu{ }^{125}$ I-oCRF ( $\sim 6,000$ counts) were added and tubes were incubated another $24 \mathrm{~h}$. After $48 \mathrm{~h}$ total incubation time, oCRF antibody was precipitated with $70 \mu$ l goat anti-rabbit gamma globulin $/ 25 \%$ polyethylene glycol. Tubes were centrifuged at $1,000 \mathrm{~g}$, the supernatants decanted, and the precipitates counted in an autogamma spectrometer. Standard tubes were set up over the range $0.1 \mathrm{pg}$ to $1 \mathrm{ng}$ OCRF. Standard curves and sample results were calculated using a microcomputer based loglogit program. 5\% and $95 \%$ confidence limits for the RIA approximated 1 and $1,100 \mathrm{pg} O C R F$. Intra- and interassay coefficients of variation were 7 and $14 \%$, respectively. Human CRF shows $10 \%$ crossreactivity in the RIA system. No cross-reactivity was observed for ACTH (synthetic 124 or crude pork), AVP, EGF, sauvagine, secretin, pancreatic polypeptide, vasoactive intestinal peptide, gastric inhibiting peptide, somatostatin, somatomedin-C, or angiotensinogen.

Statistical procedures. ACTH, AVP, E, NE, GH, heart rate, blood pressure, and blood gas responses after EGF or CRF injection were analyzed using Student's paired $t$ test, corrected as indicated for repeated measures. ACTH dose response data after CRF or EGF injection were analyzed by two-way analysis of variance (ANOVA). All data are reported as mean \pm SEM unless otherwise stated.

\section{Results}

The ACTH responses after saline, mEGF or oCRF injections are shown in Fig. 1. Baseline plasma ACTH values were similar in each instance and averaged $61 \pm 11 \mathrm{pg} / \mathrm{ml}$. There was a significant increase in plasma ACTH after injection of either oCRF or mEGF with peak values (at $60 \mathrm{~min}$ ) of $178 \pm 25$ and $191 \pm 37$ $\mathrm{pg} / \mathrm{ml}$, respectively. No increase in plasma ACTH could be demonstrated in fetuses injected with saline. Mean fetal heart rate, arterial blood pressure, and arterial blood gas values were unchanged during the study (Table I).

Plasma AVP, E, NE, and GH concentrations from the salineand EGF-treated animals are shown in Table II. Baseline AVP

Table I. Heart Rate, Mean Arterial Blood Pressure, and Blood Gases Before (0 Time) and After (+30 and +60 min) Administration of Saline, EGF, or CRF to Fetal Sheep*

\begin{tabular}{|c|c|c|c|c|c|c|c|c|c|}
\hline & \multicolumn{3}{|l|}{ Saline } & \multicolumn{3}{|l|}{ EGF } & \multicolumn{3}{|l|}{ CRF } \\
\hline & 0 & $+30 \mathrm{~min}$ & $+60 \min$ & 0 & $+30 \mathrm{~min}$ & $+60 \min$ & 0 & $+30 \min$ & $+60 \mathrm{~min}$ \\
\hline Heart rate $(B P M)$ & $163 \pm 12$ & $162 \pm 15$ & $162 \pm 13$ & $162 \pm 17$ & $164 \pm 13$ & $162 \pm 11$ & $161 \pm 11$ & $165 \pm 18$ & $164 \pm 16$ \\
\hline \multicolumn{10}{|l|}{ Mean arterial blood } \\
\hline pressure (torr) & $56 \pm 6$ & $54 \pm 5$ & $55 \pm 5$ & $55 \pm 5$ & $53 \pm 5$ & $56 \pm 7$ & $56 \pm 5$ & $53 \pm 7$ & $56 \pm 6$ \\
\hline Arterial pH & $7.38 \pm .02$ & & $7.37 \pm .02$ & $7.38 \pm .02$ & & $7.38 \pm .02$ & $7.38 \pm .01$ & & $7.39 \pm .01$ \\
\hline $\mathrm{PO}_{2}$ (torr) & $22 \pm 2$ & & $21 \pm 3$ & $21 \pm 2$ & & $22 \pm 2$ & $21 \pm 3$ & & $20 \pm 2$ \\
\hline $\mathrm{PCO}_{2}$ (torr) & $44 \pm 3$ & & $42 \pm 3$ & $44 \pm 2$ & & $44 \pm 3$ & $40 \pm 2$ & & $42 \pm 3$ \\
\hline
\end{tabular}

* All values recorded as mean and SEM. There were no significant differences among heart rate, mean arterial blood pressure or blood gases values before or after saline, EGF, or CRF treatments in these fetal lambs. 
Table II. AVP, E, NE, and GH Concentrations Before (0 time) and After (+30 or $+60 \mathrm{~min})$

Saline or EGF (10 $\mu \mathrm{g}$ Bolus) Administration in Chronically Cannulated Fetal Sheep*

\begin{tabular}{|c|c|c|c|c|c|c|}
\hline & \multicolumn{3}{|l|}{ Saline } & \multicolumn{3}{|l|}{ EGF } \\
\hline & 0 & $+30 \min$ & $+60 \mathrm{~min}$ & 0 & $+30 \min$ & $+60 \min$ \\
\hline $\operatorname{AVP}(p g / m l)$ & $2.9 \pm 0.8$ & $4.0 \pm 0.5$ & $3.2 \pm 1.1$ & $2.5 \pm 1.3$ & $2.4 \pm 1.0$ & $5.2 \pm 1.1$ \\
\hline $\mathrm{E}(p g / m l)$ & $50 \pm 14$ & $58 \pm 20$ & $67 \pm 13$ & $60 \pm 21$ & $57 \pm 22$ & $51 \pm 12$ \\
\hline $\mathrm{NE}(p g / m l)$ & $240 \pm 53$ & $190 \pm 62$ & $300 \pm 30$ & $280 \pm 41$ & $292 \pm 48$ & $220 \pm 32$ \\
\hline GH $(n g / m l)$ & $163 \pm 43$ & $161 \pm 24$ & $152 \pm 33$ & $217 \pm 26$ & $278 \pm 26$ & $155 \pm 42$ \\
\hline
\end{tabular}

* Values recorded as mean and SEM. There were no significant differences among AVP, E, NE, or GH values either before or after saline or EGF treatment in these fetal lambs.

values were similar in both groups and averaged $2.7 \pm 1.0 \mathrm{pg} / \mathrm{ml}$. AVP levels were unaffected by mEGF injection after 30 and 60 min at which times values averaged $3.7 \pm 1.0 \mathrm{pg} / \mathrm{ml}$. Baseline $\mathrm{E}$ and NE values were similar in both groups ( $E$ averaged $55 \pm 17$ $\mathrm{pg} / \mathrm{ml}, \mathrm{NE}$ averaged $260 \pm 47 \mathrm{pg} / \mathrm{ml}$ ) and unchanged after $\mathrm{mEGF}$ injection. E values after injection averaged $58 \pm 16 \mathrm{pg} / \mathrm{ml}$ and $\mathrm{NE}$ values after injection averaged $250 \pm 43 \mathrm{pg} / \mathrm{ml}$. Baseline plasma GH levels were similar in both groups and averaged $190 \pm 35 \mathrm{ng} / \mathrm{ml}$. Plasma GH levels were unchanged after 30 and $60 \mathrm{~min}$ at which time values averaged $186 \pm 38 \mathrm{ng} / \mathrm{ml}$.

Serum CRF concentrations after saline, mEGF, or oCRF injection are shown in Table III. OCRF immunoreactivity was measurable only in the sera of fetuses injected with oCRF. Serum oCRF values after $10 \mu \mathrm{g}$ of injected CRF were $6.1 \pm 1.0 \mathrm{ng} / \mathrm{ml}$ and $2.2 \pm 0.6 \mathrm{ng} / \mathrm{ml}$ at 30 and $60 \mathrm{~min}$, respectively.

ACTH dose-response data after serial mEGF and oCRF injections are shown in Fig. 2. Both mEGF and oCRF increased plasma ACTH concentrations in a dose-dependent manner. The minimal doses producing a significant ACTH response were 1 $\mu \mathrm{g}$ for EGF and $2 \mu \mathrm{g}$ for oCRF. Although no plateau in ACTH response was seen for the dosages of EGF and CRF used in these studies, CRF in the largest dose used $(20 \mu \mathrm{g})$ was associated with a greater increase in plasma immunoreactive ACTH than an equal dose of EGF.

\section{Discussion}

Three substances are known to be important regulators of ACTH release by pituitary corticotrophic cells. The first, CRF, is a 4,700$D$ peptide primarily produced by the hypothalamus and secreted into the hypothalamic-pituitary portal circulation $(27,28)$. The

Table III. Serum Immunoreactive oCRF Concentrations after Normal Saline (NS), oCRF (10 $\mu \mathrm{g})$, or $\mathrm{mEGF}(10 \mu \mathrm{g})$ Infusion in Chronically Catheterized Fetal Sheep*

\begin{tabular}{llll}
\hline & \multicolumn{2}{l}{ Immunoreactive CRF $(p g / m l)$} & mEGF \\
\cline { 2 - 3 } & NS & oCRF & $<10$ \\
\hline Baseline & $<10$ & $<10$ & $<10$ \\
+30 min & $<10$ & $6,100 \pm 1,000$ & $<10$ \\
+60 min & $<10$ & $2,200 \pm 600$ & \\
\hline
\end{tabular}

* Values recorded as mean and SEM. Sensitivity of the assay was 10 $\mathrm{pg} / \mathrm{ml}$. second, AVP, is an 1,100-D peptide produced in the hypothalamus for storage in the posterior pituitary and secretion into the pituitary portal circulation for transport to the anterior pituitary $(28,29)$. Finally, catecholamines probably augment the secretion of CRF and AVP, as well as directly modulate ACTH secretion (28).

The results of the present study indicates that EGF acts as a CRF in the fetal sheep (Figs. 1 and 2). The dose response studies indicate that EGF at low doses is at least as potent a CRF as synthetic oCRF (Fig. 2). When compared on a molar basis, EGF is a more potent CRF than synthetic CRF at dosages $<1$ nmol. However, at the highest dosages used in this study (20 $\mu \mathrm{g}$ or the equivalent of $3.2 \mathrm{nmol}$ of EGF and $4 \mathrm{nmol}$ of CRF), CRF administration is associated with nearly three times the plasma ACTH immunoreactivity when compared with EGF administration (Fig. 2). The mechanisms for these differences are not clear but may represent additional effects of CRF on AVP release, resulting in augmented ACTH responses. Our purified mouse EGF shows no crossreactivity with our anti-oCRF antiserum and does not increase circulating immunoreactive oCRF concentrations to measurable levels in the RIA. By contrast, plasma oCRF immunoreactivity increased to a level of 6.1 $\mathrm{ng} / \mathrm{ml}$ after the injection of $10 \mu \mathrm{g}$ of $\mathrm{OCRF}$ (Table III). These data suggest that EGF is not acting to provoke CRF release, although an effect on hypothalamic CRF release to increase pituitary portal blood CRF without altering peripheral levels is possible; we did not measure endogenous pituitary portal blood oCRF concentrations in the present study. Neither did EGF

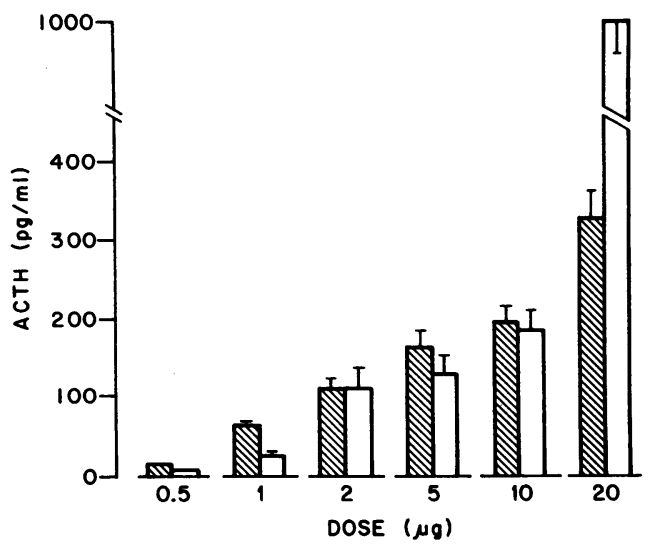

Figure 2. Plasma ACTH activity after mEGF (hatched bars) or oCRF (open bars) infusion in fetal sheep. 
stimulate AVP or catecholamine release measurable in peripheral blood (Table II). These results support the hypothesis that EGF may stimulate ACTH release via a direct action on anterior pituitary corticotrophic cells.

Circulating EGF levels after injection of EGF were not determined, but circulating levels of oCRF $30 \mathrm{~min}$ after a 10- $\mu \mathrm{g}$ injection of synthetic $O C R F$ were $6.1 \pm 1 \mu \mathrm{g} / \mathrm{ml}$ (Table III). If the plasma levels of EGF attained after a 10- $\mathrm{g}$ dose of EGF were similar, then the EGF levels would approximate plasma levels of EGF that have been reported in humans and rodents (4). This lends further support that these low levels of circulating EGF may have physiologic significance.

The oCRF peptide is comprised of 41 amino acid residues and differs from human and rat CRF by seven residues (27). Human, rat and ovine CRF share primary sequences with several nonmammalian peptides, notably sauvagine and urotensin I, and demonstrate some homology with calmodulin and angiotensinogen (27). The tetrapeptide Phe-His-Leu-Leu is common to both angiotensinogen and CRF and this sequence is the site of renin and converting enzyme cleavage (27). Comparison of $\mathrm{CRF}$, sauvagine, and urotensin I suggests that the double leucine residues at positions 14-15 and 37-38 and the basic groups at 16 and 35 are critical in preserving the ACTH releasing potencies of these peptides. Conformationally, an $\alpha$-helix for residues 5 30 and a $\beta$-bend encompassing residues $31-35$ is predicted (27).

This structure contrasts with that of EGF as defined by nuclear magnetic resonance; this protein shows a predominantly $\beta$-structure with little or no $\alpha$-helicity (30). EGF, a single polypeptide chain of 53 amino acid residues containing three disulfide bands, demonstrates $32 \%$ homology with $\alpha$-transforming growth factor, and these two substances probably bind to a similar receptor site in the target cell membrane $(31,32)$. EGF also has been reported to have $8-10 \%$ similarity in primary structure to the secretin family of peptides (gastric inhibiting peptide, glucagon, and vasoactive intestinal peptide), as well as pancreatic secretory trypsin inhibitor (33). These similarities may account for the EGF effect on gastric acid secretion. Thus, there are no homologous domains for EGF or CRF, and primary, secondary, or tertiary structural similarities would seem an unlikely explanation for the CRF-like effects of EGF.

EGF receptors are demonstrable in a number of cell lines and organs. Fetal animal studies show that liver and carcass (including skin) bind the highest amounts of EGF and that receptors are present early in gestation during the trophoblastic stage in the mouse (34). Brain receptors are described and show lower binding capacities and association constants than liver and skin receptors (34). Ontogenic studies show that although receptor numbers increase as a function of gestation, binding affinity decreases (34). In vitro studies using tumor cells derived from rat pituitaries show a dose response effect of administered EGF $(16,17)$. Saturable high affinity membrane receptors for EGF have been characterized in these cells $(15,16)$ and a recent report described EGF receptors in the normal adult rat pituitary gland (35).

Other effects of EGF on pituitary function have been described in vivo. Changes in prolactin, growth hormone, thyroid stimulating hormone, and follicle stimulating hormone have been reported $(18,36)$. Many of these studies have used very large (milligram) quantities of EGF administered over a subacute period of time and were accompanied by significant changes in cardiovascular function so that it is difficult to establish a primary effect of EGF rather than effects of these secondary changes.
Growth hormone was measured in the sera of many of the present fetuses injected with EGF and no consistent changes were seen. In vitro data suggests that EGF may alter prolactin secretion in rat pituitary tumor cells $(15,16,37)$ perhaps at the level of DNA transcription (38). Whether acute EGF administration in small doses is associated with changes in serum prolactin in vivo remains to be demonstrated.

It is possible that the ACTH response demonstrated in the current study occurred independently of a change in pituitary ACTH release. The human placenta, in addition to being a source of extrahypothalamic peptides such as gonadotropin releasing hormone, thyrotropin releasing hormone, somatotropin releasing inhibiting factor, corticotropin releasing factor, and growth hormone releasing factor, also may synthesize a proopiomelanocortin (POMC)-like substance $(39,40)$. In women, the nonsuppressibility of maternal plasma ACTH levels near term has suggested a placental source of ACTH (41). However, the control of "chorionic ACTH" production is unknown. In the mouse, the developing trophoblast contains large numbers of high affinity EGF receptors (34). Thus, an effect of EGF on chorionic POMC metabolism and ACTH production is possible.

In summary, we have demonstrated that administration of EGF to near term, chronically catheterized, ovine fetuses is associated with an increase in circulating immunoreactive ACTH concentrations. We were unable to demonstrate a change in circulating CRF, AVP or catecholamine levels in response to the EGF infusions, and dose response curves suggest that EGF is as potent a corticotropin releasing factor as synthetic oCRF at low doses. We speculate that EGF may be important in the regulation of pituitary function in developing ovine fetuses.

\section{Acknowledgments}

We thank Trudy Buenaflor for expert technical assistance in the purification of mEGF, Prescilla Barrette, Sharon Schuler, and Mary Towles for preparation of the manuscript, and Kalman Rubinson, Ph.D. and Sven Ebbeson, Ph.D. for their support of this project.

Supported by U. S. Public Health Service grant HD04270 from the National Institutes of Child Health and Human Development.

\section{References}

1. Cohen, S. 1962. Isolation of a mouse submaxillary gland protein accelerating incisor eruption and eyelid opening in the newborn animal. J. Biol. Chem. 237:1555-1562.

2. Gregory, H. 1975. Isolation and structure of urogastrone and its relationship to epidermal growth factor. Nature (Lond.) 257:325-327.

3. Carpenter, G., and S. Cohen. 1979. Epidermal growth factor. Annu. Rev. Biochem. 48:193-216.

4. Hollenberg, M. D. 1979. Epidermal growth factor-urogastrone, a polypeptide acquiring hormonal status. Vitamins. Horm. 37:69-73.

5. Gaspodarowicz, D. 1981. Epidermal and nerve growth factors in mammalian development. Annu. Rev. Physiol. 43:251-263.

6. Calvert, R., S. F. Beaulieu, and D. Menard. 1982. Epidermal growth factor accelerates the maturation of fetal mouse intestinal mucosa in utero. Experientia (Basel) 38:1096-1097.

7. Nexo, E., M. D. Hollenberg, A. Figueroa, and R. M. Pratt. 1980. Detection of epidermal growth factor-urogastrone and its receptor during fetal mouse development. Proc. Natl. Acad. Sci. USA. 77:2782-2785.

8. Barka, T., H. Van der Noen, E. W. Gresik, and T. Kerenyi. 1978. Immunoreactive epidermal growth factor in human amniotic fluid. $M t$. Sinai J. Med. 45:679-684.

9. Fisher, D. A., S. Hoath, and J. Lakshmanan. 1982. The thyroid 
hormone effects on growth and development may be mediated by growth factors. Endocrinol. Exp. 16:259-271.

10. Walker, P., M. E. Weichsel, S. B. Hoath, R. E. Poland, and D. A. Fisher. 1981. Effect of thyroxine, testosterone and corticosterone on nerve growth factor (NGF) and epidermal growth factor (EGF) concentrations in female mouse submaxillary gland: dissociation of NGF and EGF responses. Endocrinology. 109:582-587.

11. Perheentupa, J., J. Lakshmanan, and D. A. Fisher. 1984. Epidermal growth factor in neonatal mouse urine, maturative effect of thyroxine. Pediatr. Res. 18:1080-1084.

12. Hoath, S. B., J. Lakshmanan, and D. A. Fisher. 1984. Thyroid hormone effects on skin and hepatic epidermal growth factor concentrations in neonatal and adult mice. Biol. Neonat. 45:49-52.

13. Hoath, S. B., J. Lakshmanan, S. M. Scott, and D. A. Fisher. 1983. Effect of thyroid hormones on epidermal growth factor concentrations in neonatal mouse skin. Endocrinology. 112:308-314.

14. Lakshmanan, J., J. Perheentupa, S. B. Hoath, H. Kim, A. Grueters, C. Odell, and D. A. Fisher. 1985. Epidermal growth factor (EGF) in mouse ocular tissue: effect of thyroxine and exogenous EGF. Pediatr. Res. 19:315-319.

15. Mukku, V. R. 1984. Regulation of epidermal growth factor receptor levels by thyroid hormone. J. Biol. Chem. 259:6543-6547.

16. Hoath, S. B., J. Lakshmanan, and D. A. Fisher. 1985. Epidermal growth factor binding to neonatal mouse skin explants and membrane preparations-effects of triiodothyronine. Pediatr. Res. 19:277-280.

17. Johnson, L. F., J. D. Baxter, I. Vlodavsky, and D. Gospodarowicz. 1980. Epidermal growth factor and expression of specific genes: effects of cultured rat pituitary cells are dissociable from the mitogenic response. Proc. Natl. Acad. Sci. USA. 77(1):394-398.

18. Schonbrunn, A., M. Krasnoff, J. M. Westendorf, and A. H. Tashjian. 1980. Epidermal growth factor and thyrotropin-releasing hormone act similarly on a clonal pituitary cell strain. J. Cell Biol. 85:786-797.

19. Ikeda, H., T. Mitsuhashi, K. Kubota, N. Kuzuya, and H. Uchimura. 1984. Epidermal growth factor stimulates growth hormone secretion from superfused rat adenohypophyseal fragments. Endocrinology. 115:556-558

20. Scoggins, B. A., A. Butkus, J. P. Coghlan, D. T. W. Fei, J. G. McDougall, H. D. Niall, J. R. Walsh, and X. Wang. 1984. In vivo cardiovascular, renal and endocrine effects of epidermal growth factor in sheep. In Endocrinology. Proceedings of the 7th International Congress. F. Labrie, and L. Proulx, editors. Elsevier Science Publishers B. V., Amsterdam. 573-576.

21. Kaplan, S. L., M. M. Grombach, and M. L. Albert. 1976. The ontogenesis of pituitary hormones and hypothalamic factors in the human fetus: Maturation of central nervous system regulation of anterior pituitary function. Rec. Prog. Horm. Res. 32:161-234.

22. Savage, C. R. Jr., and S. Cohen. 1972. Epidermal growth factor and a new derivative. Rapid isolation procedures and biological and chemical characterization. J. Biol. Chem. 247:7609-7611.

23. Radcliffe, J. G., and C. R. W. Edwards. 1971. The extraction of adrenocorticotropin and arginine vasopressin from human plasma by porous glass. In Radioimmunoassay Methods. K. E. Kirkham, and W. M. Hunter, editors. Churchill-Livingstone, Edinburgh. 502-512.

24. Greenwood, F. C., W. M. Hunter, and J. S. Glover. 1963. The preparation of ${ }^{131}$ I-labelled human growth hormone of high specific radioactivity. Biochem. J. 89:114-123.

25. Weitzman, R. E., T. H. Glatz, and D. A. Fisher. 1978. The effects of hemorrhage and hypertonic saline upon plasma oxytocin and arginine vasopressin in conscious dogs. Endocrinology. 103:2154-2160.

26. Peuler, J. D., and G. A. Johnson. 1977. Simultaneous single isotope radioenzymatic assay of plasma norepinephrine, epinephrine and dopamine. Life Sci. 21:625-636.

27. Vale, W., C. Rivier, M. Brown, J. Spiess, G. Koob, L. Swanson, L. Bilezikjian, F. Bloom, and J. Rivier. 1983. Chemical and biological characterization of corticotropin releasing factor. Rec. Prog. Horm. Res. 39:245-270.

28. Rivier, C., and W. Vale. 1985. Effects of corticotropin-releasing factor, neurohypophyseal peptides and catecholamines on pituitary function. Fed. Proc. 44:189-195.

29. Spinedi, E., and A. Negro-Vilar. 1984. Arginine vasopressin and adrenocorticotropin release: correlation between binding characteristics and biological activity in anterior pituitary dispersed cells. Endocrinology. 114:2247-2251.

30. Mayo, K. H. 1984. Epidermal growth factor from the mouse. Structural characterization by proton nuclear magnetic resonance and nuclear Overhauser experiments at $500 \mathrm{MHz}$. Biochemistry. 23:39603973.

31. Smith, J. M., M. B. Sporal, A. B. Roberts, R. Derynck, M. E. Winkler, and H. Gregory. 1985. Human transforming growth factor causes precocious eyelid opening in newborn mice. Nature (Lond.) 315: 515-516.

32. Tam, J. P. 1985. Physiological effects of transforming growth factor in the newborn mouse. Science (Wash. DC). 229:673-675.

33. Scheving, L. A. 1983. Primary amino acid sequence similarity between human epidermal growth factor-urogastrone, human pancreatic secretory trypsin inhibitor, and members of porcine secretin family. Arch. Biochem. Biophys. 226(2):411-413.

34. Adamson, E. D., and J. Meek. 1984. The ontogeny of epidermal growth factor receptors during mouse development. Develop. Biol. 102: 62-70.

35. Chabot, S. G., P. Walker, and G. Pelletier. 1986. Distribution of epidermal growth factor binding sites in the adult rat pituitary gland. Peptides. 7:45-50.

36. Moore, G. P., B. A. Panaretto, and A. L. Wallace. 1984. Treatment of ewes at different stages of pregnancy with epidermal growth factor: effects on wool growth and plasma concentrations of growth hormone, prolactin, placental lactogen and thyroxine and on fetal development. Acta Endocrinol. 105:558-566.

37. Ramsdell, J. S., and A. H. Tashjian, Jr. 1985. Thyrotropin-releasing hormone and epidermal growth factor stimulate prolactin synthesis by a pathway(s) that differs from that used by phorbol esters: dissociation of actions by calcium dependency and additivity. Endocrinology. 117:2050-2060.

38. Murdoch, G. H., E. Potter, A. K. Nicolaisen, R. E. Evans, and M. G. Rosenfeld. 1982. Epidermal growth factor rapidly stimulates prolactin gene transcription. Nature (Lond.). 300:192-194.

39. Fisher, D. A. 1986. The unique endocrine milieu of the fetus. $J$. Clin. Invest. 78:603-611.

40. Peterson, R. E. 1983. Cortisol. In Endocrinology of Pregnancy. F. Fuchs and A. Klopper, editors. Harper and Row, Philadelphia, 3rd edition. 155-167.

41. Liotta, A., R. Osathanondh, K. J. Ryan, and D. T. Krieger. 1977. Presence of corticotropin in human placenta: demonstration of in vitro synthesis. Endocrinology. 101:1552-1558. 